\title{
CELEBRATING 20 YEARS: THE STORY OF THE SIMULATION WORKSHOP
}

\section{Prof. Stewart Robinson}

School of Business and Economics

Loughborough University

Loughborough, LE11 3TU

s.1.robinson@lboro.ac.uk
Prof. Simon J.E. Taylor

Department of Computer Science

Brunel University London

Uxbridge, UB8 3PH

simon.taylor@brunel.ac.uk

\begin{abstract}
This year marks the $10^{\text {th }}$ Operational Research Society Simulation Workshop (SW). It is over 20 years since the planning commenced for the very first SW which took place in Birmingham in March 2002. To mark this occasion, this article presents a short history of the conference including the events that led up to the first conference, details of the first SW, a summary of all $10 \mathrm{SWs}$, and how all this led to the creation of the Journal of Simulation. As founders of the conference series we provide our personal reflections on these events.
\end{abstract}

Keywords: Simulation Workshop, Conference, History

\section{INTRODUCTION}

March 2021 sees the $10^{\text {th }}$ Simulation Workshop. This, of course, has been delayed by a year due to the Covid-19 pandemic. It is, in fact, over 20 years since the planning for the inaugural workshop in 2002 started. We set-up this series of conferences following some years of running successful events through the Operational Research Society's Simulation Study Group. More correctly, we ventured to run a conference in 2002, and then one in 2004, and before we knew it the run of conferences had become a series.

On the occasion of the $10^{\text {th }}$ Simulation Workshop this paper sets out the beginnings of the conference, its history and our guiding philosophy for these events. There have been some light hearted and challenging moments along the way. What we hope to show is that two early career academics, if they put their minds to it, can create something our of nothing. As athletes often say on winning an event, 'if I can do it, anyone can.' We would encourage our colleagues to think in the same way and simply have a go. Doing so even helped us become senior academics.

In the paper we set out how we teamed-up to lead the Simulation Study Group, the developments that led to the first Simulation Workshop, the key facts, figures and events over the last 20 years, and how all this led to the Journal of Simulation. Of course, it is quite possible that we have omitted some things of importance, or misreported some of the events that took place; all such errors are probably a result of our age and certainly not deliberate attempts to misrepresent history!

\section{THE BEGINNINGS: THE SIMULATION STUDY GROUP}

The story of the Simulation Workshop started for us sometime around 1996. Stewart was a junior member of staff, indeed a Teaching Fellow on a temporary contract, at Aston University. In his annual review with the Head of the Operations and Information Management Group, Professor Colin Lewis asked him if he was involved with the OR Society's Simulation Study Group. To Stewart's shame he admitted that he had never heard of the group. Professor Lewis pointed him to the inside cover of the Journal of the Operational Research Society where it not only told him of the existence of the group, but revealed that it was being led by a certain Ray Paul and David Balmer. Somewhat embarrassed by his lack of knowledge of both the activities of 'his' Society and his chosen research field, he emailed Professor Paul to ask about the group. (At this point Stewart had known Ray for around four years, 


\section{Robinson and Taylor}

but only ever met him on US soil.) Stewart had expected to find the Study Group was a hive of activity that he had been missing out on and that it was about to transform his career. To his surprise, he discovered that the group had not met for some years. At least that explained his ignorance of the existence of the group.

Ray went on to say that the group need new leadership from someone 'like you'. For those who have worked with Ray, you will know that it is very hard to say 'no' when he makes a statement like that. Indeed, he went on to say that he had just employed a new lecturer called Simon Taylor and he thought we would do an excellent job of running the Simulation Study Group together. Simon had been a Research Fellow in the Centre for Parallel Computing at the University of Westminster working on Distributed and High Performance Simulation. Ray had had a similar conversation with him about Stewart with the 'like you' and 'no' options! Neither had any idea about who each other was, but Ray's convincing arguments sounded reasonable... and that is when we (Stewart and Simon) started to work together.

One of our earliest discussions with each other about the study group took place at the Winter Simulation Conference in San Diego in December 1996. We visited a bar in downtown San Diego, discussed ideas for the group and rather than forget them, wrote them on a menu we 'borrowed' from the bar. That menu (shown in figure 1) guided our thoughts over the next couple of years. Our other memories of that evening were that it was probably the last time Stewart was asked to prove I was over 21 by a bar attendant and having to beat a hasty retreat onto a San Diego tram as a man with a large stick was threatening us!

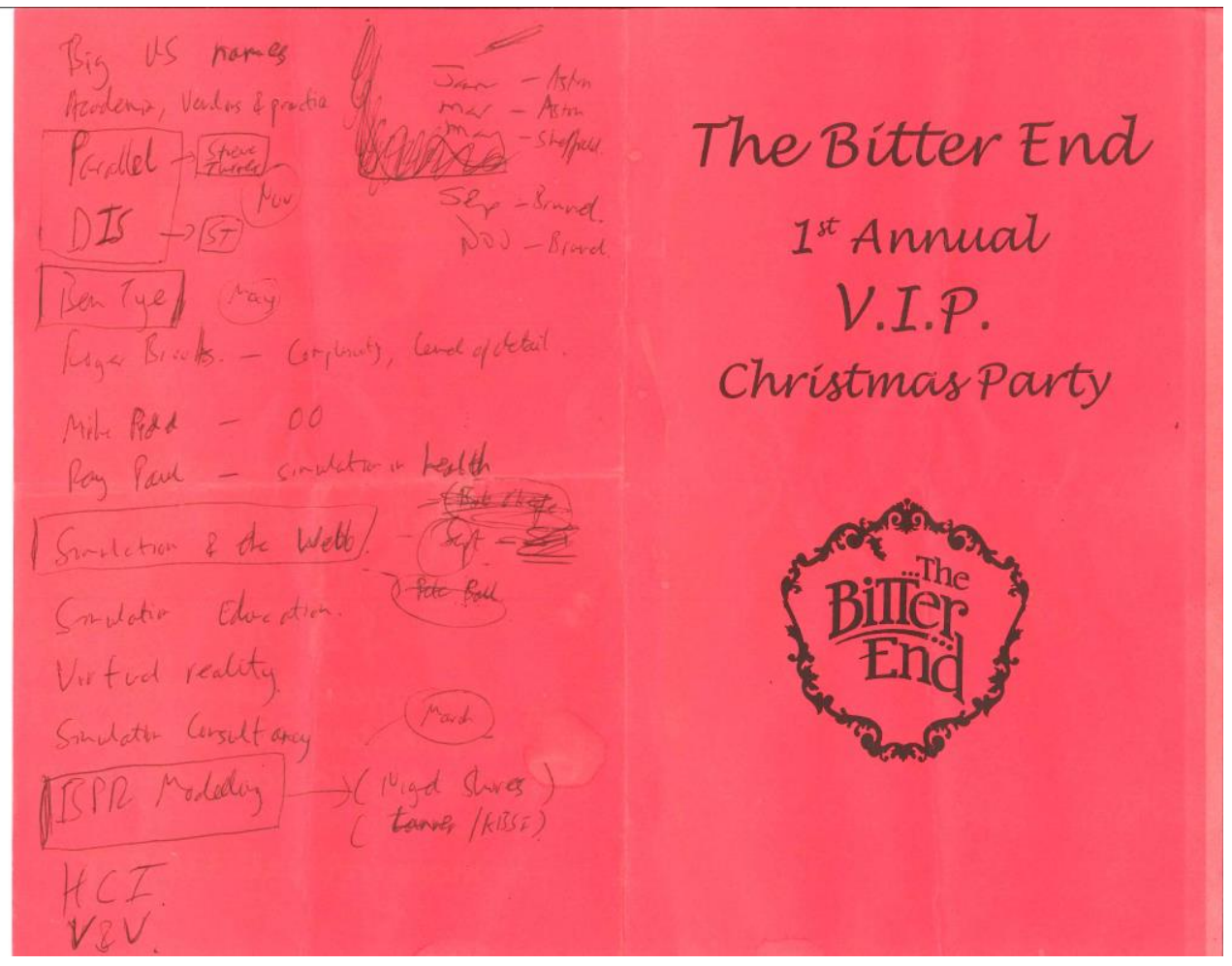

Figure 1 Study Group Plans on a San Diego Bar Menu

We organised the first of the new Simulation Study Group meetings on 29 January 1997 at Aston University in Birmingham with two speakers: John Salt and Stewart Robinson. The title of the event was 'Simulation Should be Simple and Fun: Some Do's and Don'ts of Simulation', which borrowed heavily from John's keynote talk at the 1993 Winter Simulation Conference. To our surprise around 20-30 people turned out for a two hour early evening event. One notable attendee was Sally Brailsford who had travelled from Southampton University; this was the first time that we had met her. We enthusiastically went on to organise five further meetings during 1997, although one did not run because of poor attendance. 
One thing we learnt from these meetings was that attendance at short one or two speaker events was generally quite low. So in 1998 we changed the approach and moved to a format of running two, one day meetings a year; something we continued over the next few years. The first such event was held on 24 June 1998 at Brunel University under the title 'Simulation Software: Present and Future'. The five speakers for the day were: Vlatka Hlupic (Brunel University), Steve White (British Airways), Mike Pidd (Lancaster University), Tony Waller (Lanner Group) and Ray Paul (Brunel University). Attendance at these one-day meetings was generally between 30 and 40 with the record attendance of over 70 being at a joint meeting with the UK Simulation Society organised by Susan Howick from the University of Strathclyde in April 2000: 'Discrete Event Simulation and System Dynamics: Never the Twain Shall Meet?' The paradox being that modellers from both camps did actually meet in what was an early foray into comparing these two worlds and how they might work together.

A particular facet of the study group was the involvement of both academics and practitioners. Indeed, many of the meetings included speakers from both worlds. To note that due to a change in OR Society naming conventions, the Simulation Study Group was renamed the Simulation Special Interest Group; the name it still carries today.

\section{THE FIRST SIMULATION WORKSHOP (2002)}

It was around the turn of the century when Brian Lehaney, then Chair of the OR Society's Events Committee, suggested to us that we should run a simulation conference. This was presumably as a result of the successful Study Group events we had been running. Stewart's first reaction was to say 'no'. Simon's was 'yes!!!' After all, there is a huge difference between running occasional one day events, for which there was no charge, and running a full blown conference. Stewart cannot remember what persuaded him to go ahead with the conference, but he suspects that it was Simon's more optimistic outlook on life! So somewhere early in the year 2000 we decided we would give it a go. And so what became known as the 'Simulation Study Group Two-Day Workshop', or 'Simulation Workshop' for short, was scheduled for 20-21 March 2002. The front cover of the proceedings for the original event is shown in Figure 2.

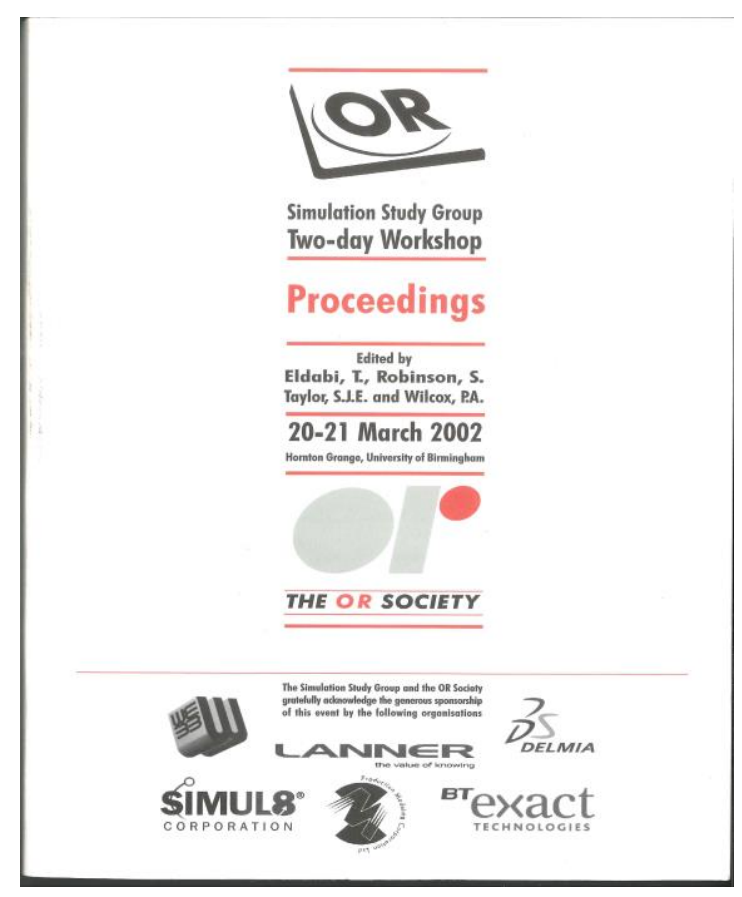

Figure 2 Proceedings Cover for the First Simulation Workshop 
We had some discussion about whether to call the event a conference, but in the end we went for the 'workshop' title. This reflected our view that the event should create an environment where academics and practitioners, from those just starting out to the well-established, shared and discussed ideas about simulation.

Over the two years of planning for the 2002 conference we developed a number of guiding principles that set the tone for future Simulation Workshops. First, we were insistent that the conference should be held in hotel type accommodation and not using student halls. If we wanted practitioners, senior academics and international visitors to attend, we knew they would expect a better quality of accommodation. We had also been tainted by an earlier experience of a conference using student accommodation; Simon woke to find a faulty spring had caused his mattress to attach itself to his knee! Stewart had slept on a similarly uncomfortable bed in the same facility, but had managed to avoid being physically assaulted by his mattress!

Second, we wanted to hold the conference in a facility that was largely, if not fully, dedicated to our delegates. We wanted people to know that if they spoke to someone else at dinner or in the bar, they were almost certainly attending the Simulation Workshop as well. The focus should be on an intensive two days for sharing and discussing ideas.

Third, we decided that all presentations should have published and reviewed papers associated with them (although there were two presentation only papers at the first conference). In doing so we followed the practice of the Winter Simulation Conference at the time. It had the benefit of helping to assure the quality of the papers presented and created an archival record of the conference. For the academics it had the added advantage of developing a first draft of a future journal paper. This requirement was relaxed a little for later Simulation Workshops when 'practice papers' were introduced; these only needed to be three pages in length. For more recent conferences this has been relaxed further and the Simulation Workshop does now have some presentation only papers. Of course, the technology for publishing the proceedings has changed over the years, moving from paper only, to CD and recently to a memory stick.

Fourth, we wanted an international keynote speaker. For 2002 Professor Richard Nance from Virginia Tech agreed to give the keynote address. Professor Nance, a leading international figure in simulation research spoke on the 'Simulation Research Agenda: Hope, Hype and Hyperbole'. In doing so he identified some of the grand challenges facing simulation at the time.

Fifth, we wanted strong representation from the simulation practitioner community. One way in which we aimed to achieve this was to invite companies to sponsor the event for a relatively low fee. In doing so they were highlighted in the conference advertising, documentation and proceedings. They were also given space in the exhibition area during the conference. Something which has become a focal point for gathering during refreshment breaks. Although we do not have detailed evidence our sense is that we have achieved a close to 50:50 split of academic and practitioner attendance.

Finally, we wanted to keep the registration fee to below $£ 300$. Something we maintained for many years and only recently has it crept above this level due, of course, to the ongoing impact of inflation.

And so we launched the workshop in the spring of 2001 with an announcement and a call for papers. Everything had to be designed from scratch: the call for papers, the author instructions, the review process, the proceedings layout, the programme for the conference, the planning timetable, etc. We also had to find a location for the event. With some guidance from Chris Barrett, the OR Society's conference organiser, we chose Hornton Grange on the edge of the Birmingham University campus. It provided good quality en-suite accommodation and a dedicated conference facility which could provide an exhibition/refreshment area and two rooms for presentations.

We arrived at Hornton Grange on $20^{\text {th }}$ March 2002 with no clue as to how well the next two days would progress. My main memory of that first conference was the opening session. We had 64 expectant delegates (we think) in the main meeting room waiting for the conference to start. Just before we opened the proceedings we remember a distinct air of 'what on earth have we done!'

\section{TEN SIMULATION WORKSHOPS: 2002-2021}

Suffice it to say that the 2002 'Simulation Study Group Two-Day Workshop' seemed to go rather well. So much so that the delegates suggested we should do it again. On further investigation the 


\section{Robinson and Taylor}

general view was that doing this on a biennial (every two years) basis would be better than doing it every year; partially to keep our sanity in organising the conference, but also to make it more of an event and to ensure the world of simulation had moved sufficiently forward between conferences.

After a six month break, we went ahead and started planning for a 2004 conference, again to be held at Hornton Grange. The '2004 Operational Research Society Simulation Workshop' used the shortened title of SW04 for the first time; a naming convention that has stuck ever since.

Table 1 Summary of Simulation Workshop Conferences

\begin{tabular}{|c|c|c|c|c|c|}
\hline Year & Location & Chair(s) & Key committee roles & Papers & Attendance \\
\hline 2002 & $\begin{array}{l}\text { Hornton Grange, } \\
\text { Birmingham }\end{array}$ & $\begin{array}{l}\text { Stewart } \\
\text { Robinson } \\
\text { Simon Taylor }\end{array}$ & $\begin{array}{l}\text { Tillal Eldabi, Pauline } \\
\text { Wilcox }\end{array}$ & 26 & 63 \\
\hline 2004 & $\begin{array}{l}\text { Hornton Grange, } \\
\text { Birmingham }\end{array}$ & $\begin{array}{l}\text { Stewart } \\
\text { Robinson } \\
\text { Simon Taylor }\end{array}$ & $\begin{array}{l}\text { Les Oakshott, Sally } \\
\text { Brailsford }\end{array}$ & 37 & 85 \\
\hline 2006 & $\begin{array}{l}\text { Ashorne Hill } \\
\text { Conference } \\
\text { Centre, Royal } \\
\text { Leamington Spa }\end{array}$ & $\begin{array}{l}\text { Stewart } \\
\text { Robinson } \\
\text { Simon Taylor }\end{array}$ & $\begin{array}{l}\text { Sally Brailsford, Jeremy } \\
\text { Garnett }\end{array}$ & 33 & 76 \\
\hline 2008 & $\begin{array}{l}\text { Abbey Hotel, } \\
\text { Redditch }\end{array}$ & $\begin{array}{l}\text { Stewart } \\
\text { Robinson } \\
\text { Simon Taylor }\end{array}$ & $\begin{array}{l}\text { Kathy Kotiadis, Christine } \\
\text { Currie }\end{array}$ & 34 & 84 \\
\hline 2010 & $\begin{array}{l}\text { Abbey Hotel, } \\
\text { Redditch }\end{array}$ & $\begin{array}{l}\text { Stewart } \\
\text { Robinson } \\
\text { Simon Taylor }\end{array}$ & $\begin{array}{l}\text { Murat Gunal, Benny } \\
\text { Tjahjono, Sally Brailsford, } \\
\text { Antuela Tako }\end{array}$ & 31 & 73 \\
\hline 2012 & $\begin{array}{l}\text { Abbey Hotel, } \\
\text { Redditch }\end{array}$ & $\begin{array}{l}\text { Benny } \\
\text { Tjahjono }\end{array}$ & $\begin{array}{l}\text { Cathal Heavy, Stephan } \\
\text { Onggo, Durk-Jouke van } \\
\text { der Zee, Thomas Monks }\end{array}$ & 32 & 74 \\
\hline 2014 & $\begin{array}{l}\text { Abbey Hotel, } \\
\text { Redditch }\end{array}$ & $\begin{array}{l}\text { Benny } \\
\text { Tjahjono }\end{array}$ & $\begin{array}{l}\text { Cathal Heavy, Stephan } \\
\text { Onggo, Durk-Jouke van } \\
\text { der Zee, Thomas Monks }\end{array}$ & 28 & 60 \\
\hline 2016 & $\begin{array}{l}\text { Ettington Chase } \\
\text { Hotel, } \\
\text { Warwickshire }\end{array}$ & $\begin{array}{l}\text { Tom Monks } \\
\text { Christine } \\
\text { Currie }\end{array}$ & $\begin{array}{l}\text { Anastasia Anagnostou, } \\
\text { Katy Hoad, Martin Kunc, } \\
\text { Anastasia Gogi }\end{array}$ & 28 & 71 \\
\hline 2018 & $\begin{array}{l}\text { Ettington Chase } \\
\text { Hotel, } \\
\text { Warwickshire }\end{array}$ & $\begin{array}{l}\text { Tom Monks } \\
\text { Christine } \\
\text { Currie }\end{array}$ & $\begin{array}{l}\text { Anastasia Anagnostou, } \\
\text { Rudabeh Meskarian, } \\
\text { Duncan Robertson, } \\
\text { Masoud Fakhimi, Tom } \\
\text { Boness }\end{array}$ & 21 & 69 \\
\hline $2021 *$ & $\begin{array}{l}\text { Burleigh Court, } \\
\text { Loughborough }\end{array}$ & $\begin{array}{l}\text { Anastasia } \\
\text { Anagnostou } \\
\text { Antuela Tako }\end{array}$ & $\begin{array}{l}\text { Masoud Fakhimi, Duncan } \\
\text { Robertson, Tom Boness, } \\
\text { Lucy Morgan, Durk-Jouke } \\
\text { van der Zee, John Fowler }\end{array}$ & $\mathrm{n} / \mathrm{a}$ & $\mathrm{n} / \mathrm{a}$ \\
\hline
\end{tabular}

* The $10^{\text {th }}$ Simulation Workshop was originally planned for March 2020, but the UK went into lockdown due to the Covid-19 pandemic a matter of a few days before the event was scheduled. As a result, the conference was postponed and then rescheduled as a virtual event for March 2021.

SW04 still holds the record for the best attended conference, with 85 delegates, although this was nearly beaten in 2018 when 84 delegates registered for SW18. Indeed, this was the only time that we had to resort to running three parallel sessions during part of the conference in order to fit in all the presentations over the two days. The number of delegates presented us with a problem as the main conference room at Hornton Grange was not large enough to seat all the attendees. We may have sneaked some extra chairs into the conference room! It was for this reason that we moved the 2006 
conference to a different location (Ashorne Hill Conference Centre near Royal Leamington Spa). SW04 was the only conference at which we did not have a panel discussion; instead we opted for a plenary session given by Brian Hollocks entitled 'Still simulating after all these years. Reflections on 40 years in simulation.' Brian submitted this as a standard paper, but we thought it was of sufficient interest to be delivered as a plenary, and it proved to be so.

Tables 1-3 summarise the details of every SIMULATION WORKSHOP conference from 2002 to 2021. Table 1 provides details of the conference location, chairs, committee members, the number of papers and attendance. Table 2 lists the keynote talks and table 3 gives details of the panel discussions at each conference.

Simon and Stewart chaired the first five conferences, eventually handing the reins over to Benny Tjahjono who, at the time, was at Cranfield University. Benny ably chaired SW12 and SW14 after which Christine Currie and Tom Monks co-chaired the next two conferences. Anastasia Anagnostou and Antuela Tako took over for this one, SW21. Key committee roles covered the delivery of the programme and proceedings, publicity and bringing together the poster session. Although the posters were initially aimed at encouraging $\mathrm{PhD}$ student participation, they have become an opportunity for other delegates to display their ideas before they are ready for a full paper. More recently there has been a prize for the best poster.

The number of papers has varied over the years, but has remained between 20 and below 40 . More recent conferences have had more keynote and plenary events, as well as tutorial sessions on the day before the main conference starts. Attendance has varied from 60 to 85 . One notable feature is that the number of attendees has always been at least double the number of papers, which suggests there is very high interest in the conference without attendees feeling the need to make a presentation.

Table 2 Keynote Talks

\begin{tabular}{|c|c|c|}
\hline Year & Keynote Speaker & Title \\
\hline 2002 & Richard Nance (Virginia Tech) & $\begin{array}{l}\text { The simulation research agenda: hope, hype and } \\
\text { hyperbole (or whence, wherefore and whither?) }\end{array}$ \\
\hline 2004 & $\begin{array}{l}\text { Paul Fishwick, University of } \\
\text { Florida }\end{array}$ & Modelling: taking it to the next level \\
\hline 2006 & $\begin{array}{l}\text { John Morecroft (London } \\
\text { Business School)* }\end{array}$ & $\begin{array}{l}\text { Representation and simulation - an information } \\
\text { feedback view }\end{array}$ \\
\hline 2008 & $\begin{array}{l}\text { Brian Hollocks (Bournemouth } \\
\text { University) }\end{array}$ & $\begin{array}{l}\text { Intelligence, innovation \& integrity - K D Tocher and } \\
\text { the dawn of simulation }\end{array}$ \\
\hline 2010 & $\begin{array}{l}\text { Charles Macal ( Argonne } \\
\text { National Laboratory) }\end{array}$ & The future of agent-based modeling and simulation \\
\hline 2012 & $\begin{array}{l}\text { Shane Henderson (Cornell } \\
\text { University) }\end{array}$ & $\begin{array}{l}\text { Real-time ambulance-fleet control via an amalgam of } \\
\text { simulation, optimization, and statistics }\end{array}$ \\
\hline 2014 & $\begin{array}{l}\text { Barry Nelson (Northwestern } \\
\text { University) }\end{array}$ & Why good simulations go bad \\
\hline $2016(\mathrm{a})$ & $\begin{array}{l}\text { Alexander Verbraeck (Delft } \\
\text { University of Technology) }\end{array}$ & Data driven simulation \\
\hline $2016(b)$ & $\begin{array}{l}\text { Sally Brailsford (University of } \\
\text { Southampton) }\end{array}$ & $\begin{array}{l}\text { Hybrid simulation: the best thing since sliced bread, } \\
\text { or just a fad? }\end{array}$ \\
\hline $2018(\mathrm{a})$ & $\begin{array}{l}\text { John Fowler (Arizona State } \\
\text { University) }\end{array}$ & $\begin{array}{l}\text { Personal reflections on the evolution of simulation } \\
\text { over the last } 20 \text { years }\end{array}$ \\
\hline $2018(b)$ & $\begin{array}{l}\text { Russell Cheng (University of } \\
\text { Southampton) }\end{array}$ & Visual representation of simulation results \\
\hline $2021(\mathrm{a})$ & $\begin{array}{l}\text { Young-Jun Son (University of } \\
\text { Arizona) }\end{array}$ & $\begin{array}{l}\text { A DDDAMS-based surveillance and crowd control } \\
\text { via UAVs and UGVs }\end{array}$ \\
\hline $2021(\mathrm{~b})$ & $\begin{array}{l}\text { Susan Sanchez (Naval } \\
\text { Postgraduate School, Monterey) }\end{array}$ & $\begin{array}{l}\text { Data farming: the meaning and methods behind the } \\
\text { metaphor }\end{array}$ \\
\hline
\end{tabular}

* Stephen Chick (INSEAD) was originally lined-up as keynote speaker but could not join us due to injury. 


\section{Robinson and Taylor}

From the beginning we sought to bring in a keynote speaker from overseas. This was not only beneficial in terms of bringing in some of the leading researchers in the field of simulation, but also a means of connecting them with the UK simulation community. We are very grateful to the willingness of these speakers to participate in and support the SIMULATION WORKSHOP conferences. They have certainly brought to our attention some current and exciting topics in simulation.

Table 3 Panel Discussions

\begin{tabular}{|c|c|c|c|}
\hline Year & Chair & Panellists & Topic \\
\hline 2002 & Stewart Robinson & $\begin{array}{l}\text { Dick Nance } \\
\text { Mike Pidd } \\
\text { Ray Paul } \\
\text { Simon Taylor }\end{array}$ & Model reuse \\
\hline 2004 & \multicolumn{3}{|c|}{ No panel discussion } \\
\hline 2006 & Mike Pidd & Not recorded & Simulation in health \\
\hline 2008 & Michael Pidd & $\begin{array}{l}\text { Stephen Chick } \\
\text { Mark Elder } \\
\text { Shane Kite } \\
\text { Ray Paul }\end{array}$ & $\begin{array}{l}\text { Simulation optimisation: the best thing since } \\
\text { sliced bread }\end{array}$ \\
\hline 2010 & Michael Pidd & $\begin{array}{l}\text { Peer Olaf Siebers } \\
\text { Charles Macal } \\
\text { Jeremy Garnett } \\
\text { Dave Buxton }\end{array}$ & DES is dead, long live ABS! \\
\hline 2012 & Sally Brailsford & $\begin{array}{l}\text { Stewart Robinson } \\
\text { Shane Henderson } \\
\text { Claire Cordeaux } \\
\text { Shane Kite }\end{array}$ & $\begin{array}{l}\text { The practice of simulation: useful, in theory? } \\
\text { The theory of simulation: practically useless? }\end{array}$ \\
\hline 2014 & Simon Taylor & $\begin{array}{l}\text { Barry Nelson } \\
\text { Mark Elder } \\
\text { Ken McNaught } \\
\text { Christine Currie }\end{array}$ & $\begin{array}{l}\text { Simulation analytics: the future of } \\
\text { simulation? }\end{array}$ \\
\hline 2016 & Christine Currie & $\begin{array}{l}\text { Stewart Robinson } \\
\text { Simon Taylor } \\
\text { John Fowler } \\
\text { Sally Brailsford }\end{array}$ & $\begin{array}{l}\text { Celebrating } 10 \text { years of the Journal of } \\
\text { Simulation }\end{array}$ \\
\hline $2018(a)$ & Kathy Kotiadis & $\begin{array}{l}\text { Sally Brailsford } \\
\text { Antuela Tako } \\
\text { Stewart Robinson } \\
\text { Christina Phillips } \\
\text { Mark Elder }\end{array}$ & $\begin{array}{l}\text { Discussing the challenges of stakeholder } \\
\text { involvement and how to overcome them }\end{array}$ \\
\hline $\begin{array}{c}2018 \\
\text { (b) }\end{array}$ & Peer Olaf Siebers & $\begin{array}{l}\text { Peer Olaf Siebers } \\
\text { Antuela Tako } \\
\text { Dave Buxton } \\
\text { Tom Monks } \\
\text { Kim Warren }\end{array}$ & $\begin{array}{l}\text { Model development strategies: from a } \\
\text { copy/paste mentality to truly innovative } \\
\text { approaches }\end{array}$ \\
\hline 2021 & Simon J E Taylor & TBC & $\begin{array}{l}\text { Artificial Intelligence and Simulation: Friend } \\
\text { or Foe? }\end{array}$ \\
\hline
\end{tabular}

In terms of keynotes, 2006 was probably the most memorable from a conference organisers point of view. Stephen Chick (INSEAD) was originally lined-up as the keynote speaker. However, he contacted us only a couple of weeks before the conference, very apologetically, to say that he had broken his leg playing ice hockey and so was unable to attend. John Morecroft stood in at the very last minute and gave a very memorable talk on system dynamics. We remain grateful to John for rescuing 
us and also to Steve who subsequently wrote-up and published his never delivered keynote address as a paper in the inaugural issue of the Journal of Simulation (Chick, 2006).

With the exception of 2004, we have always held a panel discussion on the second day of the conference. These have led to lively debates on current issues in simulation. One of the most memorable was in 2010 following Charles Macal's keynote on agent-based simulation (ABS). The title of the discussion was 'DES [discrete-event simulation] is dead, long live ABS!' In response to the proposition that DES was no longer worthwhile, Sally Brailsford later responded with her paper 'Discrete-event simulation is alive and kicking!' (Brailsford, 2014).

The Simulation Workshop started as a DES conference, but has increasingly encompassed system dynamics, ABS and hybrid simulation. The keynotes from John Morecroft (2006) and Charles Macal (2010) had a significant impact in introducing the DES community to these alternative simulation approaches.

We used the 2008 conference to celebrate the $50^{\text {th }}$ anniversary of the first simulation software. The General Simulation Program (GSP) was developed by K D Tocher at the United Steel Companies in the UK in 1958. Having worked with Tocher, we asked Brian Hollocks to give the keynote address; an excellent history of Tocher's contribution to the simulation field. A highlight was having Tocher's widow, Charlotte, and their two children in attendance. It took Stewart six months to track the family down. Charlotte, then aged 90, gave a memorable speech about her husband's work. It included a story of the press being very excited to interview Tocher because of his work on 'computer stimulation!' At SW08 we announced the launch of the K D Tocher Medal for the best paper in the Journal of Simulation, making the inaugural award in 2010. Charlotte returned to SW10 to give the award to Kathy Kotiadis.

We have always sought to ensure the conference gains international recognition. Apart from international keynote speakers, we have benefitted from international participants from Europe, Asia, the USA and as far away as Australia. Over time we have also gained 'in-cooperation' agreements from the following international societies: the INFORMS Simulation Society, ACM SIGSIM and the Society for Modeling and Simulation International.

Finally, in the long line of memorable happenings, we never expected a Simulation Workshop (SW20) to get postponed due to a global pandemic and for the conference to go fully on-line as it will in 2021. Certainly the technology would not have been available in the early years to support such a virtual event. Thanks to the dedication of the conference team it is great to know that the show will go on.'

\section{AND SO TO THE JOURNAL OF SIMULATION}

The story of the Journal of Simulation is closely aligned with the Simulation Workshop and a late night conversation with Ray Paul. During SW04 Ray suggested that, based on the success of the conference, the growing UK simulation community and the need for more journals on simulation, Simon and Stewart should start-up a new Operational Research Society journal. Our reactions were 'no' and 'yes!!!' (the reader can guess who said what!) Stewart's reservations were the huge difference between running a conference and setting-up and editing a journal from scratch. Stewart cannot remember what persuaded him to go ahead with the journal, but he suspects once again it was Simon's relentlessly optimistic attitude! (If you think you have read this before, you have, at the start of section 3 in relation to setting-up a conference.) This once again shows the impact that Ray Paul has had on us and on simulation in general.

And so the Journal of Simulation was born. After two-and-a-half years of negotiation and work, we launched the first issue of JOS at a special event in December 2006 during the Winter Simulation Conference in Monterey, California.

\section{CONCLUSION}

So 'what have we done?' First and foremost it is not what we have done; the success of the Simulation Workshop has been the result of many contributions from those that have helped organize the events, through key speakers, special guests, presenters, panelists, to attendees. One of the greatest facets of the Simulation Workshop has been the way that it brings a community of academics and 
practitioners together every two years. As we had originally envisioned, the conference has a workshop feel, where participants share and discuss ideas freely. It has become the centre piece of a very active UK simulation community. But more than that, an opportunity to showcase that community's work to the wider world and for the wider world to input to the development of simulation in the UK.

We were once asked if we would like to see the conference become much bigger. Afterall, that would surely be a measure of its success. After reflecting on this for a while, we realized that the size of the conference (60-90 delegates) was the reason for its success. Attendees are pretty much able to meet and talk with every other attendee during the two days, which is the bedrock of creating a community. So growing larger may not signify success.

One thing we do not know is whether anyone has attended all ten conferences. Simon and Stewart have both missed one Simulation Workshop (Stewart in 2010 and Simon in 2012). What we do know is that it has been hard work, it has been rewarding and above all it has been fun!

\section{ACKNOWLEDGMENTS}

We would like to acknowledge the invaluable input of Professor Ray Paul. Without his insistence that we could actually do these things the Simulation Study Group, the Simulation Workshop conferences and the Journal of Simulation would never have existed. We would also like to thank all the teams involved with each successful Simulation Workshop. We also acknowledge the incredible support of Chris Barrett and her successor Hilary Wilkes as OR Society conference organisers (especially Hilary for delving into the ORS dungeons to help us to get a complete set of all the Simulation Workshop materials). Thanks for putting up with us!

\section{REFERENCES}

Brailsford S C (2014). Discrete-event simulation is alive and kicking! Journal of Simulation 8(1): 1-8. Chick S E (2006). Six ways to improve a simulation analysis, Journal of Simulation 1(1): 21-28.

\section{AUTHOR BIOGRAPHIES}

STEWART ROBINSON is Professor of Management Science and Dean at the School of Business and Economics, Loughborough University, UK. His research interests are in the practice and use of simulation models where he focuses on conceptual modelling, model validation, output analysis and alternative simulation methods (discrete-event, system dynamics and agent based). His home page is www.stewartrobinson.co.uk.

SIMON J E TAYLOR is Professor of Computer Science, Vice Dean and Research Director of the Department of Computer Science, Brunel University London, UK. His research interests are in the advancement of academic and industrial simulation techniques and methods through novel digital technologies and in the development of digital infrastructures and simulation in Africa. He leads the Modelling \& Simulation Group (modsimg.com). Find him at https://www.brunel.ac.uk/people/simontaylor, https://orcid.org/0000-0001-8252-0189 and @ simonatbrunel. 